\title{
Pengelolaan Pariwisata Halal Pekalongan: Studi Peran Pedagang Kuliner dan Kesejahteraan Masyarakat
}

\author{
Kuat Ismanto \\ Fakultas Ekonomi dan Bisnis Islam, IAIN Pekalongan, Indonesia \\ Email: kuat.ismanto@iainpekalongan.ac.id.
}

\begin{abstract}
:
This paper aims to describe community involvement in the management of coastal halal tourism in Pekalongan Regency, Central Java, Indonesia. This research was conducted with a field research framework with a qualitative approach. Primary research data obtained through observation, interviews, and documentation. Researchers made observations in the field, as well as conducting interviews with managers of tourist objects, visitors, and traders. Secondary data is obtained through reviewing books, journal articles, research reports, data from agencies, and other sources that are in accordance with the research theme. The data obtained were analyzed using the descriptive-qualitative content analysis method and then conclusions were drawn. The results of this study indicate that coastal tourism has the potential to be developed into a halal tourism destination. The involvement of the surrounding community in managing tourist destinations has a number of benefits. Among the benefits obtained by the community are reduced unemployment, community income around tourist objects, and increased welfare, although not yet optimal.
\end{abstract}

Keywords: tourism management; coastal tourism; halal tourism; balal tourism destinations; public welfare

\begin{abstract}
Abstrak
Tulisan ini bertujuan untuk mendeskripsikan keterlibatan masyarakat dalam pengelolaan pariwisata halal pantai di Kabupaten Pekalongan Jawa Tengah Indonesia. Penelitian ini dikerjakan dengan kerangka penelitian lapangan dengan pendekatan kualitatif. Data primer penelitian diperoleh melalui observasi, wawancara, dan dokumentasi. Peneliti melakukan observasi ke lapangan, sekaligus melakukan wawancara dengan pengelola objek wisata, pengunjung, dan para pedagang. Data sekunder diperoleh melalui pengkajian terhadap buku, artikel jurnal, laporan penelitian, data dari instansi, dan sumber lainnya yang sesuai dengan tema penelitian. Data yang diperoleh dianalisis dengan metode analisis isi yang bersifat deskriptif-kualitatif yang kemudian ditarik kesimpulan. Hasil penelitian ini menunjukkan bahwa pariwisata pantai memiliki potensi untuk dikembangkan menjadi destinasi pariwisata halal. Pelibatan masyarakat sekitar dalam pengelolaan destinasi wisata memiliki sejumlah manfaat. Di antara manfaat yang diperoleh masyarakat adalah berkurangnya pengangguran, pendapatan masyarakat sekitar objek wisata, dan peningkatan kesejahteraan meskipun belum maksimal.
\end{abstract}

Kata Kunci: pengelolaan pariwisata; pariwisata pantai; pariwisata balal; destinasi pariwisata halal; kesejabteraan masyarakat 


\section{PENDAHULUAN}

Pariwisata adalah salah satu sektor penting dalam pembangunan negara atau daerah. Wisata menjadi sektor yang paling mudah dan murah untuk menyumbang Produk Domestik Bruto (PDB) ${ }^{1}$ dan juga Produk Domestik Regional Bruto (PDRB) seperti di Bali ${ }^{2}$, yang mampu meningkan Pendapatan Asli Daerah (PAD) ${ }^{3}$. Bahkan pariwisata juga menjadi alat diplomasi bagi sebuah negara, khususnya di negara-negara maju ${ }^{4}$. Di beberapa negara, sektor pariwisata dikembangkan untuk mengentaskan kemiskinan, membuka lapangan kerja ${ }^{5}$, dan peningkatan pendapatan masyarakat. Dari pentingnya sektor ini, kemudian belakangan ini dikembangkan konsep pariwisata halal, yaitu pengembangan pariwisata yang berusaha menerapkan syariat Islam ${ }^{6}$. Pariwisata halal adalah kegiatan pariwisata yang merupakan bagian dari pengembangan ekonomi Islam yang merujuk kepada al-Qur'an dan al-hadits. Konsep ekonomi Islam ini memiliki cita-cita untuk mengurangi kemiskinan, distribusi keadilan, falah (kebahagiaan dunia dan akhirat), dan lainnya ${ }^{7}$.

Bersamaan dengan itu, pemerintah Indonesia juga telah berusaha mengembangkan pariwisata halal, sebagaimana dilakukan oleh negara-negara lain seperti Malaysia, Singapura, Thailand, Jepang, dan lainnya. Indonesia sebagai negara yang memiliki ragam wisata juga telah berusaha sungguh-sungguh mengembangkan pariwisata, tidak terkecuali dengan pariwisata halal. Dari berbagai kajian menunjukkan bahwa pariwisata halal ini memiliki prospek yang baik di dunia ${ }^{8}$ dan juga Indonesia ${ }^{9}$. Bahkan, Indonesia telah memperoleh

\footnotetext{
${ }^{1}$ Dianne Dredge and Szilvia Gyimothy, Collaborative Economy and Tourism (Springer, 2016).

2 Made Antara and Made Sri Sumarniasih, "Role of Tourism in Economy of Bali and Indonesia," Journal of Tourism and Hospitality Management 5, no. 2 (2017): 34-44, https://doi.org/10.15640/jthm.v5n2a4.

3 Eva Siti Ropiah, "Wisata Halal: Potensi Ekonomi Baru Industri Pariwisata Di Kabupaten Cirebon," INKLUSIF 3, no. 2 (2018): 166-83.

4 Ade Irma and Fitri Yani, "The Development Of Islamic Economics Based On Halal Tourism In Indonesia," in Proceeding International Seminar on Islamic Studies, vol. 1, 2019, 956-66.

${ }^{5}$ Stephanie Chok, Jim Macbeth, and Carol Warren, "Tourism as a Tool for Poverty Alleviation: A Critical Analysis of 'pro-Poor Tourism' and Implications for Sustainability," Current Issues in Tourism 10, no. 23 (2007): 144-65, https://doi.org/10.2167/cit303.

${ }^{6}$ Erhan Boğan and Mehmet Sarışık, "Halal Tourism : Conceptual and Practical Challenges," Journal of Islamic Marketing, 2018, https://doi.org/10.1108/JIMA-06-2017-0066.

7 Masudul Alam Choudhury, "The Dynamics of The Shari ' Ah and The World-System," Regulators Forum Global Islamic Finance Forum: Special Session on Islamic Finance and Financial Stability Report 23, no. October (2010): 201-27.

8 Mahmonir Ghanbari and Yalda Ranjbarzadeh Tamaj, "Iran's Islamic and Halal Tourism Development Challenges," in 10 Th World Conference for Graduate Research in Tourism Hospitality and Leisure 6 Th Interdisciplinary Tourism Research Conference, ed. Metin Kozak and Nazmi Kozak (Ankara: Anatolia: An International Journal of Tourism and Hospitality Research, 2018), 194-99.

${ }^{9}$ Irma and Yani, "The Development Of Islamic Economics Based On Halal Tourism In Indonesia."
}

Iqtishadia: Jurnal Ekonomi dan Perbankan Syariah Vol.7 No.2 Desember 2020 
sejumlah penghargaan dunia atas pengelolaan pariwisata halal ${ }^{10}$. Konsep pariwisata halal yang dikembangkan di Indonesia dimaksudkan untuk menarik wisatawan luar negeri, khususnya dari Timur Tengah. Jawa Tengah juga menjadi daerah yang ditunjuk oleh pemerintah pusat, melalui Kementerian Pariwisata, untuk mengembangkan pariwisata halal, termasuk di dalam wilayah Jawa Tengah ini adalah Kabupaten Pekalongan.

Pariwisata memiliki dampak pada perekonomian, yang dapat diukur melalui dampak langsung, dampak tak langsung, dan dampak terinduksi sektor pariwisata ${ }^{11}$. Oleh karena itu, pelibatan dalam pengembangannya adalah keniscayaan. Hasil penelitian Muh Zaeni ${ }^{12}$ menunjukkan bahwa terdapat peningkatan kesejahteraan masyarakat sesudah diterapkannya pariwisata halal yang melibatkan masyarakat ${ }^{13}$. Kurniawan Gilang Widagdo ${ }^{14}$ berkesimpulan bahwa keberadaan objek wisata berdampak pada peluang usaha di sekitar objek wisata. Selain itu, juga berdampak pada peningkatan pendapatan masyarakat yang bekerja di sektor tersebut. Meski memiliki manfaat, seringkali masyarakat masih memiliki pemahaman dan kesadaran yang rendah terhadap masyarakat. Hasil penelitian Abdul Aziz ${ }^{15}$ menunjukkan bahwa rendahnya pemahaman masyarakat terhadap konsep pariwisata berdampak pada kesadaran untuk mengembangkan wisata. Persespi negatif masyarakat terhadap wisata itu disebabkan oleh ketidaktahuannya. Pemahaman terhadap konsep pariwisata yang sedang dikembangkan, bisa ditingkatkan melalui pelatihan ${ }^{16}$.

Hal penting dalam pengembangan wisata adalah keterlibatan masyarakat yang ada di sekitar objek wisata atau bahkan masyarakat yang terlibat secara langsung dengan wisata. Salah satu wujud keterlibatan masyarakat itu adalah para pedagang yang ada di dalam kawasan wisata. Kemajuan objek wisata akan ditopang oleh keberadaan pedagang kaki lima

10 CNN Indonesia, "Indonesia Peringkat Pertama Wisata Halal Terpopuler Dunia," Indonesia, CNN, 2019, https://www.cnnindonesia.com/gaya-hidup/20190409145715-269-384592/indonesiaperingkat-pertama-wisata-halal-terpopuler-dunia.

${ }^{11}$ Riatu Mariatul Qibthiyyah, “Kajian Dampak Sektor Pariwisata Terhadap Perekonomian Indonesia," 2018.

12 Muh Zaini, "Pengembangan Pariwisata Halal Berbasis Masyarakat Untuk Meningkatkan Kesejahteraan," Program Magister Ekonomi Syariah UIN Maulana Malik Ibrahim Malalng (2019), https://doi.org/10.1017/CB09781107415324.004.

13 Hefriansyah Hefriansyah, "Analisis Problematika Pengembangan Potensi Pariwisata Halal Kota Pematangsiantar Sebagai Penyangga Destinasi Prioritas Danau Toba" (Universitas Islam Negeri Sumatera Utara, 2020).

14 Kurniawan Gilang Widagdyo, "Analisis Pasar Pariwisata Halal Indonesia," The Journal of Tauhidinomics 1, no. 1 (2015): 73-80.

15 Abdul Aziz, "Peran Serta Masyarakat Dalam Upaya Pengembangan Ekowisata Di Kabupaten Pekalongan" (Universitas Sebelas Maret Surakarta, 2008).

${ }^{16}$ Ansharullah Ansharullah, Harum Natasha, and Adam Malik Indra, "Pemberdayaan Pelaku Ekonomi Sektor Melalui Peningkatan Pemahaman Konsep Wisata Syariah," Jurnal Pemberdayaan Masyarakat Madani 2, no. 2 (2018): 224-36. 
dan juga aspek lainnya ${ }^{17}$. Para pedagang yang menjajakan makanan dan minuman adalah pihak yang dibutuhkan wisatawan. Pedagang memiliki posisi tinggi jika dibandingkan dengan aspek lainnya. Untuk pedagang yang ada di dalamnya perlu memperhatikan kepentingan wisatawan $^{18}$. Sebagai contoh, jika tidak ada standar harga menu yang dijual, maka bisa berdampak pada ketidakpercayaan pengunjung. Sayangnya, pengelolaan pariwisata halal merujuk kepada indeks-indeks yang masih mengenyampingkan aspek keterlibatan masyarakat. Di antara indeks yang sering digunakan oleh para peneliti untuk mengukur pengelolaan pariwisata halal adalah GMTI ${ }^{19}$, IMTI $^{20}$, COMCEC-OIC $^{21}$, Fatwa DSN-MUI tentang penyelenggaraan pariwisata berbasis syariah $^{22}$. Untuk itu, pengelolaan pariwisata halal hendaknya melibatkan masyarakat sekitar untuk mewujudkan peningkatan kesejahteraan. Pemberdayaan dan peningkatan kesejahteraan merupakan prinsip penting dalam ekonomi Islam $^{23}$.

Kabupaten Pekalongan, sebagai salah satu wilayah yang ada di Utara Pulau Jawa memiliki dua destinasi wisata pantai, yaitu Pantai Depok Indah di Kecamatan Siwalan dan Pantai Kisik di Kecamatan Wonokerto. Keramaian kunjungan terjadi di hari minggu dan juga hari libur nasional. Kedua pantai ini, sedikit banyak, telah berkontribusi bagi pemerintah daerah dan juga masyarakat yang terlibat secara langsung maupun masyarakat di sekitar pantai. Hanya saja, menurut pengamatan penulis, kedua pantai ini belum dikelola secara maksimal sehingga kontribusinya belum signifikan bagi pemerintah daerah dan masyarakat sekitar. Salah satu hal yang terlihat kurang mendukung pengembangan pariwisata adalah fasilitas dan para pedagang yang ada di dalam kawasan wisata.

Ada banyak pihak dan faktor yang terlibat dalam pengelolaan sebuah wisata, tidak hanya pemerintah namun juga masyarakat. Untuk itu, unsur wisata yang ada di Pantai Depok Indah dan Pantai Kisik Wonokerto perlu dikelola dengan baik sehingga mampu memenuhi kepuasan wisatawan dalam menikmakti objek wisata. Objek wisata dengan tingkat kunjungan yang tinggi akan mendatangkan Pendapatan Asli Daerah (PAD) dan juga akan berdampak pada masyarakat dalam aspek ekonomi dan sosial. Wisata yang dikelola dengan

17 Kurniawati Wakhidah, Santy Dewi, and Novia Ristianti, "Bentuk Pengembangan Pariwisata Pesisir Berkelanjutan Di Kabupaten Pekalongan," Ruang: Jurnal Perencanaan Wilayah Dan Kota 1, no. 2 (2013): 261-70.

18 Elfitra Desy Surya, "Analisis Pemasaran Pariwisata Halal Di Propinsi Sumatera Barat" (Universita Sumatera Utara, 2018).

${ }^{19}$ Mastercard-CrescentRating, “Global Muslim Travel Index 2019,” 2019.

${ }^{20}$ Mastercard-CrescentRating, "Indonesia Muslim Travel Index (IMTI) 2019," Https://Www.Crescentrating.Com, 2019, https://lifestyle.okezone.com/read/2019/04/08/406/2040696/_ kalahkan-aceh-lombok-jadidestinasi- wisata-halal-nomor-satu-di-indonesia.

21 COMCEC, "Regulating Accommodation Establishments in the OIC Member Countries" (DinardStandard, 2017).

22 Dewan Syariah Nasional MUI, "Pedoman Penyelenggaraan Pariwisata Berdasarkan Prinsip Syariah," 2016.

23 Sayyid Tahir, "Islamic Economics and Prospects for Theoretical and Empirical Research," Journal of King Abdulaziz University: Islamic Economics 30, no. 1 (2017): 3-20, https://doi.org/10.4197/Islec.301.1 .

Iqtishadia: Jurnal Ekonomi dan Perbankan Syariah Vol.7 No.2 Desember 2020 
melibatkan masyarakat telah memenuhi unsur ilmu ekonomi syarih atau Islam, sebab salah satu ciri ekonomi syariah adalah memberdayakan umat. Bisnis itu tidak hanya dikuasai oleh kaum pemodal dengan mengabaikan peran serta masyarakat.

Pengelolaan pariwisata di Pekalongan akan semakin menemukan urgensinya ketika dikelola dengan konsep pariwisata halal (halal tourism) atau wisata ramah muslim (muslim friendly tourism) ${ }^{24}$. Pariwisata halal adalah sebuah konsep wisata yang mengedepankan nilainilai syariah dalam pengelolaannya ${ }^{25}$. Wisata ini bisa dimaknai sebagai sebuah upaya perluasan konsep wisata, bisa menambah yang telah ada atau bahkan bisa dimaknai sebagai wisata alternatif. Kondisi ini dimungkinkan karena Kabupaten Pekalongan secara historis maupun geografis memiliki potensi untuk itu. Disamping itu juga memiliki destinasi wisata yang beragam dan menarik, seperti kuliner, alam, reliji, bidaya, dan juga even-even wisata yang diselenggarakan secara rutin di setiap tahuannya ${ }^{26}$. Kabupaten Pekalongan juga memiliki jargon "Kota Santri", yang memiliki kepanjangan "Sehat, Aman, Nyaman, Tertib, Rapih, dan Indah" 27.

Penelitian tentang Pantai Depok di antaranya dilakukan oleh Nur Riskiyah ${ }^{28}$ yang menemukan bahwa wisata ini memiliki keterjangkauan yang tinggi dan masih mengandalkan keindahan alamnya belum banyak sentuhan tangan manusia. Aziz ${ }^{29}$ meneliti tentang peran masyarakat dalam upaya pengembangan ekowisata di Kabupaten Pekalongan yang berkesimpulan bahwa masyarakat masih memiliki persepsi yang negatif terhadap pengembangan pariwisata, maka berdampak pada kesadaran mereka untuk mengembangkan wisata di daerahnya. Hal ini disebabkan oleh minimnya pelibatan dalam proses pengembanganan ekowisata, mulai dari tahap perencanaan, tahap pengelolaan dan pemantauan/evaluasi. Menurut Syarifah Dina Fajriah \& Mussadun ${ }^{30}$ bahwa kawasan Wisata Pesisir Pantai Wonokerto belum terakodomasi dengan baik kebutuhan pengunjung seperti keberadaan sarana prasarana yang baik dan minimnya fasilitas umum pendukung yang dapat menunjang aktivitas pariwisata pengunjung. Wisata pantai sebagai bagian wisata bahari merupakan satu bentuk wisata alam yang menawarkan keindahan dan kenyamanan alami

${ }^{24}$ Intan Komalasari, "Upaya Indonesia Meningkatkan Daya Saing Muslim Friendly Tourism (MFT) Diantara Negara-Negara OKI," JOM FISIP 4, no. 2 (2017): 1-12.

${ }^{25}$ Intan Komalasari, "Upaya Indonesia Meningkatkan Daya Saing Muslim Friendly Tourism (MFT) Diantara Negara-Negara OKI," JOM FISIP 4, no. 2 (2017): 1-12.

26 Dinporapar Kabupaten Pekalongan, "Objek Wisata," Dinporapar Kabupaten Pekalongan, 2020, https://www.dinporapar-pekalongankab.web.id/index.php/view/artikel/objek_wisata.

${ }^{27}$ Pemerintah Kabupaten Pekalongan, "Lambang Dan Motto Daerah Kabupaten Pekalongan," 2020, http://pekalongankab.go.id/v2/pemerintahan/profil/lambang-moto.

${ }^{28}$ Nur Riskiyah, "Kajian Pengembangan Objek Wisata Pantai Depok Terhadap Pendapatan Asli Daerah," Jurnal Ilmiah Geografi, 2019, https://adoc.tips/kajian-pengembangan-objek-wisata-pantai-depokterhadap-penda.html.

${ }^{29}$ Aziz, "Peran Serta Masyarakat Dalam Upaya Pengembangan Ekowisata Di Kabupaten Pekalongan."

${ }^{30}$ Syarifah Dina Fajriah and Mussadun -, "Pengembangan Sarana Dan Prasarana Untuk Mendukung Pariwisata Pantai Yang Berkelanjutan (Studi Kasus: Kawasan Pesisir Pantai Wonokerto Kabupaten $\begin{array}{lllll}\text { Pekalongan)," JURNAL PEMBANGUNAN WILAYAH \& } & \text { KOTA, 2014, }\end{array}$ https://doi.org/10.14710/pwk.v10i2.7653. 
dari kombinasi sinar matahari, laut, dan pantai berpasir yang bersih (3S - Sun, Sea, and Sand $)^{31}$.

Tulisan ini berusaha untuk mendeskripsikan keterlibatan masyarakat dalam pengelolaan pariwisata halal pantai di Kabupaten Kabupaten Pekalongan dalam kerangka pariwisata halal. Kajian diawali dari pemetaan fasilitas infrastruktur pendukung wisata. Selanjutanya melihat keterlibatan masyarakat dalam pengelolaan pariwisata pantai, khususnya keberadaan para pedagang makanan. Dari dua aspek di atas, kemudian dilihat dampaknya terhadap perkembangan objek wisata dan juga kemanfaatannnya bagi masyarakat sekitar. Pantai yang menjadi fokus penelitian ini adalah Pantai Depok Indah dan Pantai Kisik atau dikenal juga dengan Pantai Wonokerto. Dua pantai ini dipilih dengan pertimbangan bahwa dua pantai tersebut dikunjungi oleh masyarakat, tidak hanya dari Pekalongan, tetapi juga dari luar daerah. Disamping itu, dua pantai dikelola oleh pihak yang berbeda, Pantai epok oleh Pemerintah Kabupaten melalui Dinas Pariwisata, sedangkan Pantai Kisik oleh Pemerintah Desa melalui BUMDes.

\section{METODE PENELITIAN}

Penelitian ini dikerjakan dengan kerangka penelitian lapangan (field research) yaitu penelitian megeksplorasi secara intensif tentang latar belakang keadaan sekarang, dan interaksi suatu sosial, individu, kelompok, lembaga, dan masyarakat ${ }^{32}$. Data primer penelitian dikumpulkan melalui observasi dan wawancara. Peneliti melakukan observasi pada saat hari libur dan hari kerja. Peneliti melakukan wawancara dengan pengelola, pedagang, dan pengunjung destinasi wisata. Data-data dokumentasi digunakan oleh peneliti untuk mendukung hasil wawancara dan observasi. Data dokumentasi diperoleh melalui penelusuran terhadap website Pemerintah Kabupaten Pekalongan. Data sekunder berupa buku, artikel jurnal, data statistik diperoleh dari sumber dan pihak yang berwenang dan telah divalidasi. Data yang terkumpul dianalisis secara deskriptif kualitatif sejak dilakukan pengumpulan data di lapangan. Yang dimaksud dengan penelitian deskriptif adalah prosedur pemecahan masalah yang diselidiki dengan mengambarkan/melukiskan keadaan subjek/objek penelitian (seseorang, lembaga, masyarakat, dan lain-lain) pada saat sekarang berdasarkan fakta-fakta yang tampak atau sebagaimana adanya ${ }^{33}$. Validitas data diuji dengan menggunakan metode triangulasi sumber antara pengelola wisata, pedagang, dan juga masyarakat sebagai pengunjung.

\section{HASIL DAN PEMBAHASAN}

\section{Potensi Kabupaten Pekalongan sebagai Destinasi Pariwisata Halal}

Kajian tentang wisata pantai di Pakalongan ini dibahas dalam kerangka pariwisata ramah muslim (muslim friendly tourism), yaitu pariwisata yang fokus utamanya memenuhi

\footnotetext{
${ }^{31}$ Sri Nurhayati Qodriyatun, "Implementasi Kebijakan Pengembangan Pariwisata Berkelanjutan Di Karimunjawa," Aspirasi: Jurnal Masalah-Masalah Sosial 9, no. 2 (2018): 240, http://jurnal.dpr.go.id/index.php/aspirasi/index.

32 Burhan Bungin, Penelitian Kualitatif: Komunikasi, Ekonomi, Kebijakan Publik, Dan Ilmu Sosial Lainnya, Kencana, 2011, https://doi.org/10.1002/jcc.21776.

${ }^{33}$ Hadari Nawawi, Metode Penelitian Bidang Sosial (Yogyakarta: Gajah Mada University Press, 1998).
}

Iqtishadia: Jurnal Ekonomi dan Perbankan Syariah Vol.7 No.2 Desember 2020 
kebutuhan wisatawan muslim yang tidak ingin berkompromi atas kebutuhan dasar seperti jaminan fasilitas amenitas berlabel sertifikasi halal yang mencakup basis iman ajaran agama ketika melakukan aktivitas wisata ${ }^{34}$. Pembangunan sektor wisata di tingkat nasional maupun daerah dikembangkan dalam rangka meningkatkan kunjungan wisatawan, baik nasional maupun internasional. Dari peningkatan kunjungan ini diharapkan dapat menambah Pendapatan Asli Daerah (PAD), devisa, terbukanya lapangan pekerjaan, penurunan tingkat kemiskinan, dan lain. Menurut Ridhwan (dalam Tambunan) ${ }^{35}$ bahwa wisata bisa menjadi sumber pertumbuhan ekonomi baru, pariwisata mendorong tumbuhnya usaha jasa dan industri berbasis lokal, sektor wisata "siap jual" untuk menghasilkan devisa dibanding yang lain.

Kabupaten Pekalongan memiliki dua kondisi wilayah utama, yaitu pantai dan pegunungan. Di setiap wilayah ini memiliki objek wisata yang khas sesuai dengan jenisnya masing-masing. Di wilayah Selatan, yang pegunungan terdapat wisata alam Linggo Asri, Kali Paingan, Curug Bajing, Gran Canyon, dan lain sebagainya. Sedangkan di wilayah Utara terdapat pariwisata pantai dan pariwisata belaja batik, seperti International Batik Centre (IBC). Di wilayah ini juga terdapat Kampung Batik Kemplong Wiradesa ${ }^{36}$ yang menarik serta sejalan dengan wisata pantai. Bentuk-bentuk wisata itu bisa dilihat pada gambar 1.

${ }^{34}$ Komalasari, "Upaya Indonesia Meningkatkan Daya Saing Muslim Friendly Tourism (MFT) Diantara Negara-Negara OKI," 2017.

35 Tulus T.H. Tambunan, Pembangunan Ekonomi Perdesaan Berbasis Industri Kreatif Dan Pariwisata (Bandung: CV. Pustaka Setia, 2019).

${ }^{36}$ Panji W Angga, "Kampung Batik Kemplong Wiradesa," Cinta Pekalongan, 2020, https://www.cintapekalongan.com/kampung-batik-kemplong-wiradesa/.

Iqtishadia: Jurnal Ekonomi dan Perbankan Syariah Vol.7 No.2 Desember 2020 


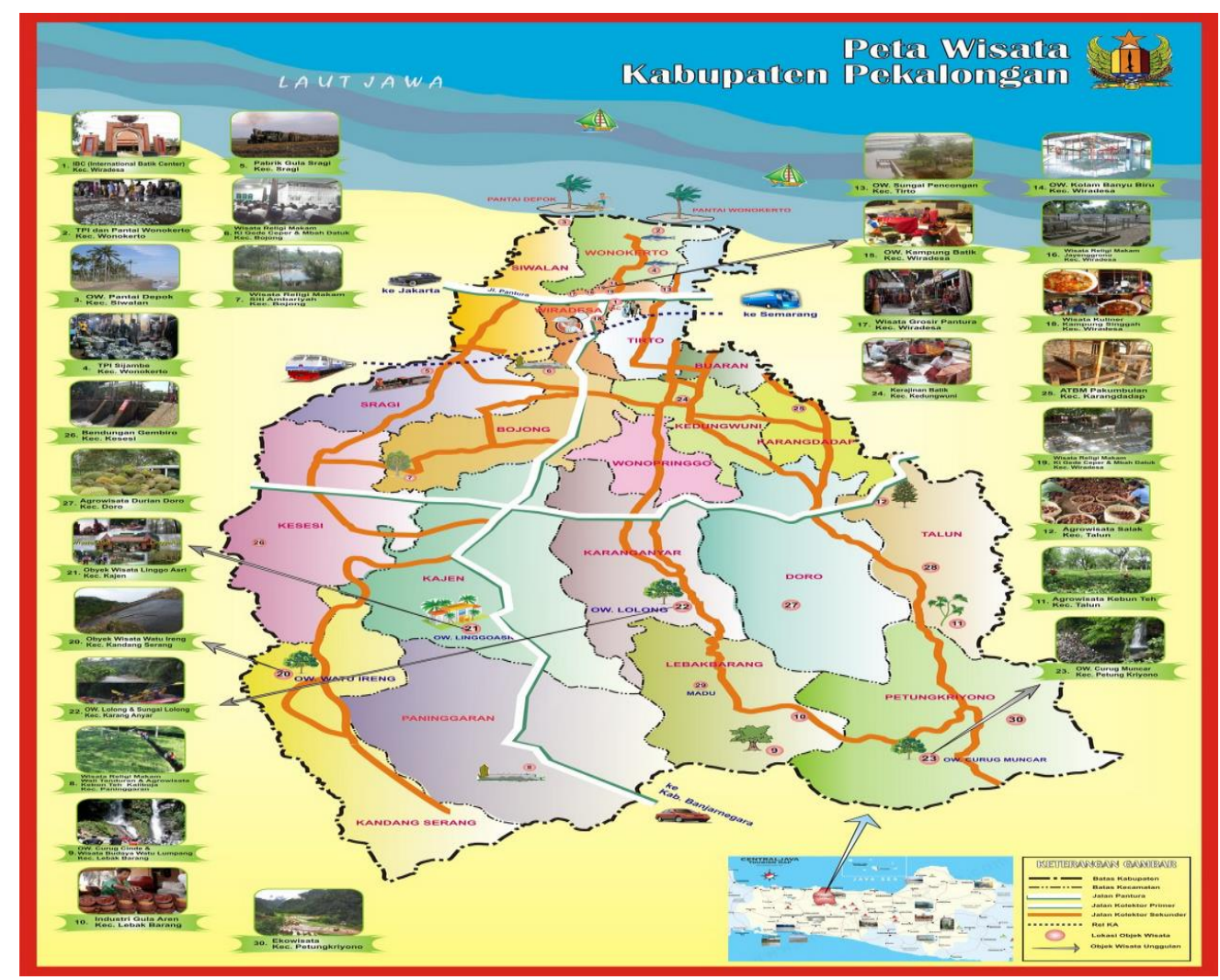

Gambar 1.

Peta Wisata Kabupaten Pekalongan

Dari gambar 1 di atas, wisata di sebelah utara yang berupa pantai, pemerintah bisa memberi penjelasan ke pengunjung batik di IBC untuk mengunjungi wisata pantai di sebelah Utara yang jaraknya tidak terlalu jauh. Oleh karena itu, wisatawan dan pengunjung tidak hanya berbelanja batik, tetapi juga bisa berwisata pantai. Akomodasi berupa hotel/ penginapan di wilayah ini juga cukup representatif, yaitu keberadaan hotel, termasuk yang berbasis syariah. Keberadaan tempat ibadah, seperti masjid dan mushola juga mudah untuk dijumpai.

Salah satu cara mengukur kelayakan pariwisata adalah merujuk kepada komponen wisata yang terdiri dari atraksi, akses, aksesibilitas, dan kelembagaan wisata ${ }^{37}$. Empat aspek tersebut ada di Kabupaten Pekalongan dan kondisinya cukup mendukung pengembangan pariwisata halal. Daerah di sekitar Kabupaten, seperti Kota Pekalongan, Kabupaten Batang, dan Kabupaten Pemalang bisa menjadi pendukung pengembangan pariwisata ini.

Uraian di atas telah menunjukkan bahwa Kabupaten Pekalongan di wilayah Utara memiliki faktor pendukung wisata yang baik. Destinasi wisata yang ada di sekitar jalur

${ }_{37}$ Chris Cooper and C. Michael Hall, Contemporary Tourism: An International Approach, Contemporary Tourism: An International Approach, 2007, https://doi.org/10.4324/9780080554990.

Iqtishadia: Jurnal Ekonomi dan Perbankan Syariah Vol.7 No.2 Desember 2020 
pantura bisa mendukung wisata Pantai Depok Indah dan Pantai Kisik Wonokerto. Oleh karena itu, Kabupaten Pekalongan memiliki potensi menjadi destinasi wisata ramah muslim atau bisa disebut dengan pariwisata halal. Komitmen pemerintah untuk mengembangkan dalam rangka meningkatkan kesejahteraan bagi masyarakat sangat terbuka. Namun demikian, dukungan masyarakat untuk mengembangkan juga tidak bisa diabaikan. Hal ini menjadi penting ketika konsep pariwisata berbasis masyarakat atau dikenal juga dengan pariwisata berkelanjutan (sustainable tourism) telah berhasil dijalankan di beberapa wilayah di Indonesia ${ }^{38}$.

\section{Pengelolaan Pariwisata Pantai Kabupatan Pekalongan}

\section{Pantai Depok Indah Pekalongan}

Pantai Depok Indah Pekalongan dikelola oleh pemerintah daerah melalui Dinas Pendidikan, Olahraga, dan Pariwisata (Dindikpora) Kabupaten Pekalongan. Hanya saja bentuk atau representasi pengelolaan itu tidak begitu tampak atau masih minimalis. Yang ada di objek wisata adalah petugas tiket yang berada di pintu masuk objek wisata. Penjaga keamanan pantai atau petugas kebersihan tidak dijumpai di pantai Depok maupun pantai Wonokerto. Kondisi ini kurang menjamin keamanan dan kenyamanan wisatawan yang sedang bermain di pantai. Tanda larangan "Tidak Boleh Berenang” kurang cukup memadai untuk dijadikan peringatan bagi wisatawan.

Hal utama yang paling menjadi pertimbangan wisatawan, baik lokal maupun mancanegara ketika mengunjungi objek wisata adalah kemudahan untuk menjangkaunya. Pantai Depok Indah Pekalongan atau sering disingkat dengan PDIP adalah salah satu destinasi wisata yang ada di wilayah Utara Kabupaten Pekalongan tepatnya di Kecamatan Siwalan. Objek ini berjarak kurang lebih 2 KM ke arah Utara dari Jalan Nasional Pantura Jawa. Pantai ini menawarkan pemandangan pantai yang menawan, dimana pepohonan yang banyak dan rimbun memberi keteduhan suasana. Pasir hitam dan ombak kecil ditawarkan oleh keindahan pantai ini. Wisata keluarga yang murah dan cukup mudah dijangkau. Tahun 2017 pantai ini dikunjungi sebanyak 1.546 wisatawan lokal $^{39}$.

Di sepanjang perjalanan menuju objek wisata, wisatawan akan disuguhi pemandangan sawah di sebelah kanan dan sungai di sebelah kiri. Di sawah ini, juga sering terlihat para petani sedang bercocok tanam, baik membajak, menanam, atau bahkan sedang menyiangi (matun). Sebelum sampai lokasi, tepatnya di dekat menuju pantai terdapat tambak ikan dan juga peternakan ayam dengan kandang diatas sawah, yang tampak seperti mengapung. Adapun di tepi sungai, sesekali tampak para pemancing dan orang menener ikan. Dan yang pasti, di sepajang pinggir jalan juga dikelilingi pohon mahoni dan juga cemara yang menambah suasana rindang. Aktifitas masyarakat tersebut bisa dinikmati sebagai wisata kehidupan. Meski di kanan-kiri sawah dan sungai, wisatawan tidak perlu khawatir berlebihan, sebab disepanjang jalan akan ditemui rumah penduduk, meskipun jaraknya tidak

38 Tambunan, Pembangunan Ekonomi Perdesaan Berbasis Industri Kreatif Dan Pariwisata.

39 Open Data Kabupaten Pekalongan, "Jumlah Kunjungan Wisata Alam Pantai Depok," Kabupaten Pekalongan, 2017, http://data.pekalongankab.go.id/dataset/jumlah-kunjungan-wisata-alam-pantaidepok/resource/e6c95f63-72bf-4ab9-a848-3001068f0d55.

146

Iqtishadia: Jurnal Ekonomi dan Perbankan Syariah Vol.7 No.2 Desember 2020 
berdekatan. Warung kelontong dan penjual bensin eceran juga akan ditemui, sesekali juga penjual ikan dan udang terutama pagi hari.

Di area Pantai Depok, terasa rindang dan adem sebab terdapat pepohonan yang cukup banyak. Pantai ini lebih enak jika dikunjungi pada pagi hari atau sore hari, tetapi siang hari juga tetap indah untuk dinikmati. Ombak yang tidak cukup besar atau tinggi cukup aman untuk bermain, tetapi harus tetap waspada. Pasir pantai warna hitam yang cukup bersih serta kerang-kerang kecil bisa menjadi permainan anak-anak. Di pantai juga dipasang bebatuan yang menjorok ke laut, yang digunakan untuk memecah gelombang. Tidak jarang, bebatuan ini digunakan untuk berswafoto alias selfie. Di lokasi itu juga sering digunakan oleh pengunjung untuk memancing ikan. Hanya saja, abrasi air laut telah merusak bibir pantai.

Warung makan dan jajanan juga terdapat di area wisata yang berjumlah 10 warung. Meskipun sudah ditata dalam satu area, akan tetapi penampilannya kurang menarik. Warung-warung ini menjual nasi megono, bakso, mie ayam, dan juga minuman panas, seperti kopi dan teh. Makanan dan minuman ringan juga tersedia, terutama makanan dan minuman produk industri. Adapun harga untuk makanan dan minuman cukup murah dan terjangkau. Untuk menikmatinya, pedagang menyediakan meja dan kursi di pinggiran pantai. Di beberapa pohon, juga dipasang ayunan sebagai fasilitas untuk konsumen menikmati pemandangan pantai.

Fasilitas umum juga tersedia, seperti area parkir dan toilet umum. Tempat parkir berada di dalam objek wisata, baik untuk mobil maupun motor. Jaraknya tidak jauh dengan bibir pantai. Adapun toilet, nampaknya ada beberapa warung juga menyediakan dengan tarif Rp.2000,-. Bersamaan dengan toilet, ada juga tempat bilas maupun ganti baju bagi pengunjung yang ingin membersihkan badan setelah berenang. Untuk sarana MCK, dipandang cukup untuk memenuhi kebutuhan pengunjung meski kebersihannya perlu ditingkatkan.

Dari uraian ini, peneliti berpandangan bahwa pengelolaan wisata PDI-P kurang maksimal, seperti promosi yang masih kurang dan infrastruktur. Sebab, objek wisata ini ramai jika di hari libur saja, selainnya belum maksimal. Padahal di lokasi memiliki potensi untuk dikembangkan lebih optimal lagi, seperti dijadikan wisata edukasi sumber daya air dan alam, seperti pelestarian hutan mangrove. Terlebih, jika destinasi wisata ini dikembangkan menjadi pariwisata halal (halal tourism), seperti di Lombok, Aceh, dan atau daerah lainnya. sebab, Kabupaten Pekalongan telah memiliki modal untuk mengembangkan konsep pariwisata halal.

\section{Pantai Kisik Wonokerto}

Di sebelah Timur Pantai Depok, terdapat Pantai Kisik yang ada di Kecamatan Wonokerto. Pantai ini dikelola oleh Badan Usaha Milik Desa (BUMDes) Desa Wonokerto Kulon. Sama halnya dengan pantai Depok, pantai ini ramai dikunjungi wisatawan lokal di hari minggu dan juga hari libur. Pengunjung tidak hanya orang tua dan dewasa, tetapi juga ada anak-anak. Beberapa pengunjung dari luar daerah yang sedang menempuh pendidikan di wilayah Pekalongan. Dengan demikian pantai ini potensial untuk dikunjungi oleh wisatawan dari laur daerah.

Kondisi jalan menuju objek wisata dibilang cukup baik, kombinasi jalan cor, aspal, dan juga paving kondisinya baik. Oleh karena itu jalan layak dilalui kendaraan, baik roda dua

Iqtishadia: Jurnal Ekonomi dan Perbankan Syariah 
maupun roda empat. Hanya saja kendaraan publik atau masal seperti angkutan desa atau kota tidak tersedia. Pemnadangan sepanjang jalan menuju pantai terdapat sungai yang kondisinya airnya keruh yang di sisinya terdapat tanaman mangrove. Di sepanjang jalan itu pula ada jemuran ikan masin milik masyarakat sekitar. Di sepanjang jalan mendekati pantai terdapat tambak ikan yang cukup luas. Sesekali tampak para pemancing ikan di tambak. Menurut penulis pemandangan awal menujuk objek wisata ini perlu ditata, supaya kesan menyenangkan sudah ditangkap oleh wisatawan. Untuk itu diperlukan sosialisasi wisata kepada masyarakat di sepanjang jalan menuju objek wisata.

Memasuki objek wisata, pengunjung diwajibkan membayar tiket dan juga biaya parkie kepada petugas tiket. Setiap pengunjung dikenakan biaya Rp.2.000,- dan biaya parkir untuk satu kendaraan roda empat sebesar Rp.1.000,-. Hanya saja, pengunjung dikenakan biaya untuk toilet. Area parkir cukup luas, baik untuk roda dua maupun roda empat. Secara umum, kondisinya aman dan nyaman bagi kendaraan. Dalam konteks sekarang, dengan harga tiket sebesar itu sudah tidak lagi memadai, maka menaikkan harga adalah sebuah keharusan. Hasil penjualan tiket ini bisa digunakan untuk menambah fasilitas wisata, sehingga nilai manfaatnya akan kembali kepada pengunjung.

Secara umum, pantai Wonokerto ini dikatakan pemandangannya indah. Ombak yang tidak terlalu besar, bisa dinikmati pengunjung untuk berenang meskipun harus dengan kehati-hatian. Destinasi utama objek wisata ini adalah pemandangan laut, pasir, dan juga permainan ombak laut. Namun demikian, pengelola telah menambah destinasi tambahan berupa permainan, seperti trampolin, seni menggambar bagi anak, serta kereta "odongodong". Papan tanda bahaya dan penjaga keamanan pantai tidak ada. Selain menikmati keindahan pantai, pengunjung bisa menikmati swafoto yang telah disediakan. Miniatur perahu dan bangunan menjadikan pengunjung bisa melakukan selfie. Fasilitas tambahan seperti "kereta odong-odong" dan juga mainan kreatifitas gambar juga tersedia.

Di pantai ini juga tersedia tempat ibadah bagi umat Islam berupa mushola. Kondisi mushola ini nampaknya masih baru sehingga masih baik dan cukup bersih. Hanya saja fasilitas pendukungnya kurang memadai, seperti tenpat wudhu yang masih terbuka. Satu kran air digunakan oleh jama'ah laki-laki maupun perempuan. Jumlah sarung dan mukena masih sedikit, belum sebanding dengan jumlah pengunjung. Kondisi ini belum sepenuhnya mendukung konsep wisata halal sebagaimana dirumuskan oleh Satriana \& Faridah $^{40}$, Mohamed M. Battour, dkk ${ }^{41}$. Wilayah Pekalongan yang dikenal dengan daerah yang agamis, maka sudah seharusnya di setiap objek wisata disediakan fasilitas ibadah yang memadai.

Secara umum kedua pantai ini telah didukung oleh fasilitas pendukung wisata. Diantara fasilitas pendukung itu adalah keberadaan para pedagang makanan-minuman, toilet umum, area parkir, kamar mandi ganti pakaian, dan juga sarana pendukung lainnya. Meski begitu, semuanya masih perlu ditingkatkan kuantitas maupun kualitasnya. Kondisi ini

40 Eka Dewi Satriana and Hayyun Durrotul Faridah, "Wisata Halal: Perkembangan, Peluang, Dan Tantangan," Journal of Halal Product and Research 01, no. 02 (2018): 32-43.

41 Mohamed M. Battour, Mohd Nazari Ismail, and Moustafa Battor, "Toward a Halal Tourism Market," Tourism Analysis 15, no. 4 (2010): 461-70, https://doi.org/10.3727/108354210X12864727453304. 
nampaknya tidak jauh berbeda dengan temuan Wakhidah, dkk. ${ }^{42}$ yang menyatakan bahwa sarana-prasarana belum memadai dan juga sistem tata kelola wisata yang belum paripurna.

Bentuk keterlibatan masyarakat di kedua objek wisata ini adalah menjadi pengelola pantai dan menjadi pedagang di dalam objek wisata. Di beberapa sudut lokasi wisata terdapat warung, yang menjajakan makanan dan minuman. Di antara makanan yang dijual adalah "sego megono", yaitu makanan khas Pekalongan yang terbuat dari gori nangka muda. Di samping itu, terdapat juga makanan ringan. Pelibatan masyarakat di objek wisata ini, menurut penulis sudah menunjukkan iktikad baik, meskipun belum maksimal. Sebab, wisata yang melibatkan masyarakat adalah wisata yang memenuhi prinsip ekonomi syariah, yaitu pemberdayaan, upaya untuk mewujudkan kemaslahatan umat ${ }^{43}$.

Beberapa hal yang mungkin perlu diperhatikan guna memenuhi standar wisata pantai yang memadai, maka perlu diadakan petugas keamanan pantai. Petugas ini bisa ditugasi secara khusus untuk mengawasi pantai, baik keamanan ketertiban masyarakat maupun mengawasi pengunjung yang sedang berenang. Di kedua pantai ini nampaknya belum lengkap dan kurang maksimal. Selama ini yang ada di sana adalah petugas jaga masuk yang menarik karcis saja. Menurut Ridhwan (dalam Tambunan) ${ }^{44}$ bahwa ada dua kendala pengelolaan wisata di desa, termasuk wisata pantai, adalah faktor kelembagaan, baik formal maupun informal yang terlibat secara langsung dengan wisata. Faktor kedua adalah persoalan kemanan. Sehebat apap pun destinasi wisata menjadi daya tarik, jika dari sisi keamanan tidak mendukung, maka wisatawan akan enggan berkunjung. Sondakh ${ }^{45}$ juga menyampaikan pentingnya keamanan bagi pengembangan wisata. Langkah yang bisa dilakukan adalah pengelola wisata bekerjasama dengan pihak masyarakat lokal, polisi, perusahan, dan koramil ${ }^{46}$.

\section{Pedagang sebagai Pendukung Pariwisata Halal}

Lucky Nugroho, dkk. ${ }^{47}$ menyatakan bahwa pengelolaan wisata hendaknya tidak berorientasi pada wisatawan, tetapi sudah mengarah pada ecosytem-oriented. Ekosistem bisnis wisata halal adalah elemen-elemen yang mencakup seluruh stakeholder seperti pemerintah, masyarakat, pelaku bisnis dan seluruh industri terkait yang mendukung bisnis wisata halal. Semua aspek bersinergi dalam rangka memberikan layanan terbaik (excellent

\footnotetext{
42 Wakhidah et al. (2013)

43 Muhammad Abdul Mannan, "WHY IS ISLAMIC ECONOMICS IMPORTANT?" (Jeddah - Saudi Arabia, 1982).

44 Tambunan, Pembangunan Ekonomi Perdesaan Berbasis Industri Kreatif Dan Pariwisata.

45 PNM Sondakh, "Pelayanan, Keamanan Dan Daya Tarik Mempengaruhi Minat Wisatawan Yang Berkunjung Ke Objek Wisata Alam Gunung Mahawu, Tomohon," Jurnal Berkala Ilmiah Efisiensi 16, no. 1 (2016), ejournal.unsrat.ac.id.

46 Zaenal Fanani and Edriana Pangestuti, "Analisis Keamanan Dan Kenyamanan Objek Wisata Penanjakan 1 Bromo," Jurnal Administrasi Bisnis 49, no. 2 (2017): 63-67.

47 Lucky Nugroho, Wiwik Utami, and Caturida Meiwanto Doktoralina, "Ekosistem Bisnis Wisata Halal Dalam Perspektif Maqasid Syariah (Halal Tourism Business Ecosystem in the Maqasid Syariah Perspective)," Islamic Banking and Finance Journal 3, no. 2 (2019): 84-92, https://doi.org/10.21070/perisai.v3i2.1964.
} 
services) kepada para wisatawan yang datang berkunjung. Salah satu hal penting dalam pengelolaan wisata adalah masyarakat yang terlibat di dalam wisata.

Para pedagang yang ada di objek wisata ini tergabung dengan asosiasi pedagang. Jadi tidak semua orang begitu saja menjadi penjual di dalam objek wisata. Pedagang tidak dibatasi terhadap produk yang dijual. Ragam produk yang dijual diantaranya, dari makanan tradisional sampai dengan produk olahan industri. Produk lokal yang dijual oleh pedagang diantaranya gorengan, batagor, es cendol, es kelapa muda, kue leker, nasi megono, dan jenis makanan lainnya. Adapun makanan produk olahan industri diantaranya makanan cepat saji, makanan kecil, minuman, dan makanan sejenis lainnya. Hanya saja jaminan kehalalannya belum bisa dipastikan, kecuali makanan olahan industri yang telah ada logo halal MUI. Menurut $^{48}$ bahwa wisatawan laki-laki lebih memilih fasilitas ibadah dan makanan halal, sedangkan wisatawan perempuan memilih kerahasiaannya sebagai perempuan.

Hasil observasi penulis di lapangan bahwa penataan lapak para pedagang kurang rapi. Bangunan lapak pedagang terbuat dari kayu seadanya, sesekali dipasang MMT sebagai nama warung, sehingga kontra dengan gedung bangunan yang telah dikerjakan oleh pemerintah. Bangunan baru berupa gasebo dan gedung pertemuan tersebut telah digunakan oleh masyarakat, seperti kelompok PKK untuk mengadakan rapat. Ada informasi bahwa dalam waktu dekat akan dibangun lapak permanen dengan sistem sewa. Informasi ini menjadi kabar baik prospek pariwisata bagi Kabupaten Pekalongan.

Berkaitan dengan objek wisata pantai ini, beberapa pengunjung menyampaikan bahwa ia telah beberapakali mengunjungi objek wisata ini. Alasan yang disampaikan adalah bahwa pantai ini suasananya teduh karena banyak pohon. Selain itu, di pantai ini tersedia banyak tempat duduk. Tempat duduk ini, baik yang disediakan oleh pengelola maupun para pedagang penjual makanan. Setiap meja dikelilingi oleh kursi sekaligus payung warna-warni sebagai peneduh. Kursi yang dibentuk nyentrik untuk berswafoto juga tersedia.

\section{Kemanfaatan Pengelolaan Pariwisata Pantai bagi Masyarakat}

Menurut Mohamed Battour, $\mathrm{dkk}^{49}$ pariwisata telah berubah orientasi, yang semula bertujuan untuk pembangunan, tetapi telah dirubah untuk mengurangi kemiskinan. Seiring perkembangan kaum milenial Indonesia yang telah menempatkan pengeluaran untuk melakukan perjalanan wisata, pengelola wisata harus menangkap peluang ini dengan baik. Tren belanja pariwisata ini menjadi salah satu porsi belanja utama, apalagi ditunjang kemajuan teknologi digital ${ }^{50}$. Bagi mereka, pariwisata tidak sekedar menjadi gaya hidup, tetapi telah menjadi kebutuhan hidup. Meski demikian, pariwisata harus dikembangkan dalam rangka meningkatkan kesejahteraan masyarakat.

Keberadaan para pedagang yang ada di objek wisata Pantai di Kabupaten Pekalongan patut untuk diapresiasi. Selain itu, pelibatan masyarakat sebagai pengelola, seperti menjadi

\footnotetext{
${ }^{48}$ Mohamed Battour, Mohd Nazari Ismail, and Moustafa Battor, "The Impact of Destination Attributes on Muslim Tourist 's Choice," INTERNATIONAL JOURNAL OF TOURISM RESEARCH 540, no. December 2010 (2011): 527-40, https://doi.org/10.1002/jtr.824.

${ }^{49}$ Battour, Ismail, and Battor.

${ }^{50}$ Tambunan, Pembangunan Ekonomi Perdesaan Berbasis Industri Kreatif Dan Pariwisata.
} 
penjaga tiket, petugas parkir, dan lainnya, juga tidak bisa diabaikan sebagai bentuk pengelolaan yang baik. Dengan pelibatan masyarakat ini berarti pariwisata telah memiliki orientasi dan manfaat yang baik bagi masyarakat. Jika pariwisata pantai ini dikembangkan denan baik akan berdampak pada masyarakat seperti penyerapan tenaga kerja, pendapatan para pekerja, dan juga peningkatan pendapatan daerah seperti di Kabupaten Semarang ${ }^{51}$.

Beberapa pedagang memberi kesaksian bahwa pekerjaannya menjadi pedagang di objek wisata pantai ini telah memberi kemanfaatan bagi diri dan keluarganya. Diantara bentuk kemanfaatan itu adalah terbukanya lapangan pekerjaan, bertambahnya penghasilan, dan meningkatnya kualitas hidup keluarga. Para pedagang ini juga melibatkan keluarga dalam melayani wisatawan. Adapun mayoritas pedagang berasal dari desa yang dekat dengan objek wisata. Meski demikian dukungan pemerintah untuk melengkapi komponen wisata sangat diharapkan. Peran pemerintah dalam mendukung sangat penting, karena ia adalah bagian dari ekosistem wisata $^{52}$. Produk wisata yang menarik akan membuat wisatawan berkunjung kembali. Keberlanjutan wisata pantai ini harus dijaga karena telah memberi manfaat kepada masyarakat.

\section{PENUTUP}

Dari uraian hasil penelitian dan pembahasan maka dapat disimpulkan sebagai berikut; (1) Destinasi wisata pantai di Kabupaten Pekalongan memiliki potensi untuk dikembangkan menjadi pariwisata halal. Komponen pariwisata yang berupa atraksi, akses, amenitas, dan juga fasilitas lainnya, bisa dijadikan modal. (2) Bentuk dan pola keterlibatan masyarakat dalam pengelolaan destinasi wisata di Pantai Kisik Wonokerto lebih baik daripada Pantai Depok Indah. Pengelola Pantai Wonkerto adalah Pemerintah Desa melalui BumDes, sedangkan Pantai Depok dikelola oleh Pemerintah Daerah. (3) Kedua pantai telah melibatkan masyarakat untuk mengembangkan wisata, terutama untuk menjadi pedagang di objek wisata. Keterlibatan sebagai pedagang ini ternyata telah membantu masyarakat dalam membuka lapangan pekerjaan dan meningkatkan penghasilan. Pelibatan masyarakat dalam tata kelola wisata menumbuhkan rasa tangggung jawab terhadap objek wisata.

Dari uraian di atas, maka ada beberpa saran yang bisa dijalankan oleh stakeholder wisata pantai Depok maupun Wonokerto, diantaranya (1) bagi pemerintah untuk meningkatkan sarana-prasarana fisik wisata dan juga memberi pelatihan softskill bagi para pedagang terkait dengan layanan ke para pengunjung. Dua hal ini pemerintah bisa merujuk kepada konsep wisata ramah muslim dalam rangka mewujudkan visi misi dan motto Kabupaten Pekalongan; (2) bagi para pengelola di lapangan dan juga para pedagang kaki lima untuk memiliki rasa tanggung jawab atas keberlanjutan wisata pantai, sebab objek wisata tersebut adalah sumber penghasilan bagi keluarga.

51 Wawan Kurniawan, "Dampak Sosial Ekonomi Pembangunan Pariwisata Umbul Sidomukti Kecamatan Bandungan Kabupaten Semarang," Economics Development Analysis Journal 4, no. 4 (2015): 443-51, https://doi.org/10.15294/edaj.v4i4.14851.

52 Nugroho, Utami, and Doktoralina, "Ekosistem Bisnis Wisata Halal Dalam Perspektif Maqasid Syariah (Halal Tourism Business Ecosystem in the Maqasid Syariah Perspective)."

Iqtishadia: Jurnal Ekonomi dan Perbankan Syariah Vol.7 No.2 Desember 2020 


\section{DAFTAR PUSTAKA}

Angga, Panji W. "Kampung Batik Kemplong Wiradesa." Cinta Pekalongan, 2020. https://www.cintapekalongan.com/kampung-batik-kemplong-wiradesa/.

Ansharullah, Ansharullah, Harum Natasha, and Adam Malik Indra. "Pemberdayaan Pelaku Ekonomi Sektor Melalui Peningkatan Pemahaman Konsep Wisata Syariah." Jurnal Pemberdayaan Masyarakat Madani 2, no. 2 (2018): 224-36.

Antara, Made, and Made Sri Sumarniasih. "Role of Tourism in Economy of Bali and Indonesia." Journal of Tourism and Hospitality Management 5, no. 2 (2017): 34-44. https://doi.org/10.15640/jthm.v5n2a4.

Aziz, Abdul. "Peran Serta Masyarakat Dalam Upaya Pengembangan Ekowisata Di Kabupaten Pekalongan." Universitas Sebelas Maret Surakarta, 2008.

Battour, Mohamed, Mohd Nazari Ismail, and Moustafa Battor. "The Impact of Destination Attributes on Muslim Tourist' s Choice." INTERNATIONAL JOURNAL OF TOURISM RESEARCH 540, no. December 2010 (2011): 527-40. https://doi.org/10.1002/jtr.824.

Battour, Mohamed M., Mohd Nazari Ismail, and Moustafa Battor. "Toward a Halal Tourism Market." Tourism Analysis 15, no. 4 (2010): 461-70. https://doi.org/10.3727/108354210X12864727453304.

Boğan, Erhan, and Mehmet Sarışık. "Halal Tourism : Conceptual and Practical Challenges." Journal of Islamic Marketing, 2018. https://doi.org/10.1108/JIMA-06-2017-0066.

Bungin, Burhan. Penelitian Kualitatif: Komunikasi, Ekonomi, Kebijakan Publik, Dan Ilmu Sosial Lainnya. Kencana, 2011. https://doi.org/10.1002/jcc.21776.

Chok, Stephanie, Jim Macbeth, and Carol Warren. "Tourism as a Tool for Poverty Alleviation: A Critical Analysis of 'pro-Poor Tourism' and Implications for Sustainability." Current Issues in Tourism 10, no. 2-3 (2007): 144-65. https://doi.org/10.2167/cit303.

Choudhury, Masudul Alam. "The Dynamics of The Shari ' Ah and The World-System." Regulators Forum Global Islamic Finance Forum: Special Session on Islamic Finance and Financial Stability Report 23, no. October (2010): 201-27.

COMCEC. "Regulating Accommodation Establishments in the OIC Member Countries." DinardStandard, 2017.

Cooper, Chris, and C. Michael Hall. Contemporary Tourism: An International Approach. Contemporary Tourism: An International Approach, 2007. https://doi.org/10.4324/9780080554990.

Dinporapar Kabupaten Pekalongan. “Objek Wisata.” Dinporapar Kabupaten Pekalongan, 2020. https://www.dinporaparpekalongankab.web.id/index.php/view/artikel/objek_wisata.

Dredge, Dianne, and Szilvia Gyimothy. Collaborative Economy and Tourism. Springer, 2016. 
Fajriah, Syarifah Dina, and Mussadun -. "Pengembangan Sarana Dan Prasarana Untuk Mendukung Pariwisata Pantai Yang Berkelanjutan (Studi Kasus: Kawasan Pesisir Pantai Wonokerto Kabupaten Pekalongan)." JURNAL PEMBANGUNAN WILAYAH \& KOTA, 2014. https://doi.org/10.14710/pwk.v10i2.7653.

Fanani, Zaenal, and Edriana Pangestuti. "Analisis Keamanan Dan Kenyamanan Objek Wisata Penanjakan 1 Bromo.” Jurnal Administrasi Bisnis 49, no. 2 (2017): 63-67.

Ghanbari, Mahmonir, and Yalda Ranjbarzadeh Tamaj. "Iran's Islamic and Halal Tourism Development Challenges." In 10 Th World Conference for Graduate Research in Tourism Hospitality and Leisure 6 Th Interdisciplinary Tourism Research Conference, edited by Metin Kozak and Nazmi Kozak, 194-99. Ankara: Anatolia: An International Journal of Tourism and Hospitality Research, 2018.

Hefriansyah, Hefriansyah. "Analisis Problematika Pengembangan Potensi Pariwisata Halal Kota Pematangsiantar Sebagai Penyangga Destinasi Prioritas Danau Toba." Universitas Islam Negeri Sumatera Utara, 2020.

Indonesia, CNN. "Indonesia Peringkat Pertama Wisata Halal Terpopuler Dunia." Indonesia, CNN, 2019. https://www.cnnindonesia.com/gaya-hidup/20190409145715-269384592/indonesia-peringkat-pertama-wisata-halal-terpopuler-dunia.

Irma, Ade, and Fitri Yani. "The Development Of Islamic Economics Based On Halal Tourism In Indonesia." In Proceeding International Seminar on Islamic Studies, 1:956-66, 2019.

Komalasari, Intan. “Upaya Indonesia Meningkatkan Daya Saing Muslim Friendly Tourism (MFT) Diantara Negara-Negara OKI." JOM FISIP 4, no. 2 (2017): 1-12.

_-_. "Upaya Indonesia Meningkatkan Daya Saing Muslim Friendly Tourism (MFT) Diantara Negara-Negara OKI." JOM FISIP 4, no. 2 (2017): 1-12.

Kurniawan, Wawan. "Dampak Sosial Ekonomi Pembangunan Pariwisata Umbul Sidomukti Kecamatan Bandungan Kabupaten Semarang." Economics Development Analysis Journal 4, no. 4 (2015): 443-51. https://doi.org/10.15294/edaj.v4i4.14851.

Mannan, Muhammad Abdul. “WHY IS ISLAMIC ECONOMICS IMPORTANT?” Jeddah - Saudi Arabia, 1982.

Mastercard-CrescentRating. “Global Muslim Travel Index 2019,” 2019.

_-_. "Indonesia Muslim Travel Index (IMTI) 2019." Https://Www.Crescentrating.Com, 2019. https://lifestyle.okezone.com/read/2019/04/08/406/2040696/kalahkan-acehlombok-jadi-destinasi- wisata-halal-nomor-satu-di-indonesia.

MUI, Dewan Syariah Nasional. "Pedoman Penyelenggaraan Pariwisata Berdasarkan Prinsip Syariah," 2016.

Nawawi, Hadari. Metode Penelitian Bidang Sosial. Yogyakarta: Gajah Mada University Press, 1998.

Nugroho, Lucky, Wiwik Utami, and Caturida Meiwanto Doktoralina. "Ekosistem Bisnis Wisata

Iqtishadia: Jurnal Ekonomi dan Perbankan Syariah

Vol.7 No.2 Desember 2020 
Halal Dalam Perspektif Maqasid Syariah (Halal Tourism Business Ecosystem in the Maqasid Syariah Perspective)." Islamic Banking and Finance Journal 3, no. 2 (2019): 8492. https://doi.org/10.21070/perisai.v3i2.1964.

Pekalongan, Open Data Kabupaten. "Jumlah Kunjungan Wisata Alam Pantai Depok." Kabupaten Pekalongan, 2017. http://data.pekalongankab.go.id/dataset/jumlahkunjungan-wisata-alam-pantai-depok/resource/e6c95f63-72bf-4ab9-a8483001068f0d55.

Pemerintah Kabupaten Pekalongan. "Lambang Dan Motto Daerah Kabupaten Pekalongan," 2020. http://pekalongankab.go.id/v2/pemerintahan/profil/lambang-moto.

Qibthiyyah, Riatu Mariatul. “Kajian Dampak Sektor Pariwisata Terhadap Perekonomian Indonesia," 2018.

Qodriyatun, Sri Nurhayati. "Implementasi Kebijakan Pengembangan Pariwisata Berkelanjutan Di Karimunjawa.” Aspirasi: Jurnal Masalah-Masalah Sosial 9, no. 2 (2018): 240. http://jurnal.dpr.go.id/index.php/aspirasi/index.

Riskiyah, Nur. "Kajian Pengembangan Objek Wisata Pantai Depok Terhadap Pendapatan Asli Daerah." Jurnal Ilmiah Geografi, 2019. https://adoc.tips/kajian-pengembangan-objekwisata-pantai-depok-terhadap-penda.html.

Ropiah, Eva Siti. "Wisata Halal: Potensi Ekonomi Baru Industri Pariwisata Di Kabupaten Cirebon." INKLUSIF 3, no. 2 (2018): 166-83.

Satriana, Eka Dewi, and Hayyun Durrotul Faridah. "Wisata Halal: Perkembangan, Peluang, Dan Tantangan." Journal of Halal Product and Research 01, no. 02 (2018): 32-43.

Sondakh, PNM. "Pelayanan, Keamanan Dan Daya Tarik Mempengaruhi Minat Wisatawan Yang Berkunjung Ke Objek Wisata Alam Gunung Mahawu, Tomohon." Jurnal Berkala Ilmiah Efisiensi 16, no. 1 (2016). ejournal.unsrat.ac.id.

Surya, Elfitra Desy. "Analisis Pemasaran Pariwisata Halal Di Propinsi Sumatera Barat." Universita Sumatera Utara, 2018.

Tahir, Sayyid. "Islamic Economics and Prospects for Theoretical and Empirical Research." Journal of King Abdulaziz University: Islamic Economics 30, no. 1 (2017): 3-20. https://doi.org/10.4197/Islec.30-1.1.

Tambunan, Tulus T.H. Pembangunan Ekonomi Perdesaan Berbasis Industri Kreatif Dan Pariwisata. Bandung: CV. Pustaka Setia, 2019.

Wakhidah, Kurniawati, Santy Dewi, and Novia Ristianti. "Bentuk Pengembangan Pariwisata Pesisir Berkelanjutan Di Kabupaten Pekalongan." Ruang: Jurnal Perencanaan Wilayah Dan Kota 1, no. 2 (2013): 261-70.

Widagdyo, Kurniawan Gilang. "Analisis Pasar Pariwisata Halal Indonesia." The Journal of Tauhidinomics 1, no. 1 (2015): 73-80.

154

Iqtishadia: Jurnal Ekonomi dan Perbankan Syariah Vol.7 No.2 Desember 2020 
Pengelolaan Pariwisata Halal Pekalongan: Studi Peran Pedagang Kuliner dan Kesejahteraan Masyarakat

Zaini, Muh. "Pengembangan Pariwisata Halal Berbasis Masyarakat Untuk Meningkatkan Kesejahteraan." Program Magister Ekonomi Syariah UIN Maulana Malik Ibrahim Malalng, 2019. https://doi.org/10.1017/CB09781107415324.004.

Iqtishadia: Jurnal Ekonomi dan Perbankan Syariah Vol.7 No.2 Desember 2020 